\title{
Prey consumption by the mealybug predator Spalgis epius on pink hibiscus mealybug (Maconellicoccus hirsutus)
}

\author{
Anegunda S. Dinesh • Melally G. Venkatesha
}

Received: 11 July 2010 /Accepted: 28 October 2010 /Published online: 10 November 2010

(C) Springer Science+Business Media B.V. 2010

\begin{abstract}
The pink hibiscus mealybug Maconellicoccus hirsutus (Green) (Hemiptera: Pseudococcidae) is a major pest of economically important crops. The apefly Spalgis epius (Westwood) (Lepidoptera: Lycaenidae) is a potential predator of various species of mealybugs. Studies of its preying potential and preference for prey stages on $M$. hirsutus are incomplete. An investigation was undertaken to determine the daily prey consumption and preference for prey stages by different larval instars of $S$. epius reared on M. hirsutus in the laboratory. During the 8day larval development period with four larval instars of S. epius, the daily prey consumption increased from the first to the seventh day and decreased on the eighth day prior to the prepupal stage. Generally, there was a significant difference in the prey consumption on different days. The 1st to 4th instar larvae of $S$. epius consumed, respectively, a mean of $181.3,679.1,1770.4$ and 4333.0 eggs or $19.1,67.7$, 153.0 and 639.0 nymphs or 2.72, 6.26, 13.8 and 32.1 adults of M. hirsutus. When an S. epius larva was fed on $M$. hirsutus eggs, nymphs and adults separately, it consumed a mean of 6952.6 eggs, 878.8 nymphs or 53.9 adults during its entire development. A single larva of $S$. epius consumed 2358.3 eggs, 151.2 nymphs and 34.3 adults of $M$. hirsutus during its
\end{abstract}

A. S. Dinesh • M. G. Venkatesha $(\bowtie)$

Department of Zoology, Bangalore University,

Bengaluru 560056, India

e-mail: venkatmelally@gmail.com entire development when the prey stages were offered all together. The study revealed that $S$. epius is a voracious predator of $M$. hirsutus and thus could be utilized as a potential biological control agent.

Keywords Apefly · Biocontrol agent · Lycaenidae ·

Prey stages

\section{Introduction}

Different species of mealybugs are serious pests of economically important crops worldwide (Browning 1992; Franco et al. 2001). Of them, Maconellicoccus hirsutus (Green) (Hemiptera: Pseudococcidae) is a major pest of numerous economically important crops such as grapes, citrus, avocado, carambola, fig, guava, mango, sugarcane and mulberry; vegetable crops including asparagus, beans, beets, cabbage, peanuts, pigeon pea, cucumber, lettuce, pepper, pumpkin, and tomato; forest trees, many species of ornamental plants; and various fruits and shade trees in both tropical and subtropical countries (Hoy et al. 2002; Kairo et al. 2000; Reddy et al. 2009; Roltsch et al. 2006). M. hirsutus adults lay 300-600 eggs and complete the life cycle in 23-30 days with three (female) and four (male) nymphal instars (Hoy et al. 2002). M. hirsutus is the only species in the genus that has a worldwide distribution (Meyerdirk et al. 2002). Annual economic losses due to this pest have been estimated at approximately $\$ 2.5$ million in 
Grenada, \$5.1 million in Trinidad and \$750 million in the United States, and to cause severe economic losses in Egypt and India (Kairo et al. 2000). Reddy et al. (2009) studied interactions of M. hirsutus and its natural enemies in Guam. Roltsch et al. (2006) reported that two species of parasitoids reduced $98 \%$ of $M$. hirsutus density in southern California.

The apefly Spalgis epius (Lepidoptera: Lycaenidae: Miletinae) has been recorded as a predator of various species of mealybugs, viz., Dactylopius sp., Planococcus virgatus (Ckll.), P. lilacinus (Ckll.), P. citri (Risso), Ferrisia virgata (Ckll.), and Paracoccus marginatus Williams and Granara de Willink (Homoptera: Pseudococcidae), and M. hirsutus (Dinesh et al. 2010; Thangamalar et al. 2010); and a scale insect Chloropulvinaria polygonata (Ckll.) (Homoptera: Coccidae) (Ali 1978). Of the several insect predators of mealybugs in India, the larva of $S$. epius has been reported as a potential predator of $P$. citri and P. lilacinus in coffee plantations (Chacko et al. 1977; Rahiman and Vijayalakshmi 1998), and $M$. hirsutus in mulberry gardens (Gowda et al. 1996). Long ago, India imported an important predator Cryptolaemus montrouzieri Mulsant (Coleoptera: Coccinellidae) for the control of different species of mealybugs (Rao et al. 1971).

Spalgis epius occurs in India, Burma and Sri Lanka (Bingham 1907), Philippines and Java (Le Pelley 1943), Bangladesh (Ali 1978), and Thailand (Lohman and Samarita 2009). The morphology, development, life history and behavior of S. epius has been studied (De Niceville 1890; Vinod Kumar et al. 2006; Dinesh et al. 2010; Thangamalar et al. 2010). Observations on the behavior of $S$. epius and its interaction with ants have been made in the field (Venkatesha et al. 2004; Venkatesha 2005; Vinod Kumar et al. 2008a). Vinod Kumar et al. (2008b) and Thangamalar et al. (2010) observed the predatory potential of S. epius on $P$. citri and $P$. marginatus, respectively, by offering all the prey stages together. Furthermore, brief field observations have been made of the feeding activities of S. epius on P. citri and P. lilacinus in coffee Coffea canephora Pierre ex Froehner (Rahiman and Vijayalakshmi 1998), of M. hirsutus in mulberry Morus alba L. (Pushpaveni et al. 1973), and of $P$. lilacinus in the ber crop Zizyphus mauritiana L. (Mani and Krishnamoorthy 1996) in India.

Although $S$. epius is a potential predator of $M$. hirsutus, no detailed study has been made of the daily prey consumption by developing $S$. epius larvae on different prey stages of the pest offered together and separately. Hence, the present study was undertaken to assess its daily and instar-wise prey consumption, and preference for different prey stages such as eggs, nymphs and adults of $M$. hirsutus in the laboratory. This information is essential to utilize $S$. epius as a major biological control agent of $M$. hirsutus in the field.

\section{Materials and methods}

Lab rearing of prey Maconellicoccus hirsutus was reared in the laboratory following the method used for rearing Planococcus citri (Anon. 1995). The medium sized ( $\approx 70 \mathrm{~cm}$ diam and $20 \mathrm{~cm}$ height) ripe pumpkins (Cucurbita maxima Duchesne) with ridges and grooves, with a small stalk for handling, were selected for rearing $M$. hirsutus. The pumpkins were thoroughly washed with tap water and then dipped in $0.1 \%$ fungicide (Bovistin) to kill the fungal pathogens. The eggs and nymphs of $M$. hirsutus were collected with a camel hair brush from hibiscus plants, Hibiscus rosa sinensis L. (Malvaceae), in the field of Bangalore University campus, Bengaluru, India (latitude $12^{\circ} 58^{\prime} \mathrm{N}$, longitude $77^{\circ} 35^{\prime} \mathrm{E}$, elevation 921 masl) and transferred onto cleaned pumpkins in the laboratory. The M. hirsutus-infested pumpkins were maintained individually in a nylon rearing cage $(30 \times 30 \times 30 \mathrm{~cm})$ and reared. For regular availability of prey, fresh pumpkins were infested with $M$. hirsutus whenever needed.

Lab rearing of predator Spalgis epius larvae from the laboratory culture were reared on the pumpkins infested with $M$. hirsutus and completed their development on those pumpkins. Emerged adults of S. epius were allowed to mate and the gravid females of $S$. epius were provided with fresh mealybuginfested pumpkins for egg deposition. The laboratory cultured population of $S$. epius was used for the experiment.

Prey consumption The experiments on prey consumption by $S$. epius were conducted in the laboratory at $28.0 \pm 1.0^{\circ} \mathrm{C}, 65 \pm 5 \%$ r.h., and photoperiod $12 \mathrm{~L}: 12 \mathrm{D}$ in an environmental chamber. The prey consumption of $S$. epius was assessed by 
offering different $M$. hirsutus stages (i.e., eggs, 2nd instar nymphs and adults) separately and together.

In order to determine the prey consumption potential of $S$. epius larva, the eggs of $S$. epius laid in the mass of mealybugs on the pumpkin were collected carefully with a fine camel hair brush and kept individually in petri dishes ( $5 \mathrm{~cm}$ diam). Newly emerged larvae from these eggs were maintained in the same petri dishes and provided with a daily known number of egg masses, nymphs and adults of $M$. hirsutus separately as food until they reached the prepupal stage. The prey eggs, nymphs and adults were counted under a stereo zoom microscope. Based on the preliminary laboratory observations, the prey stages were offered to $S$. epius larvae daily in quantities pre-determined according to the predator age to ensure that the available prey-food exceeded the amount that the predator could consume in a day. The number of eggs, nymphs and adults of the prey consumed by $S$. epius larva was recorded at 24$\mathrm{h}$ intervals by counting the remaining prey stages in the petri dish. The larval excreta and left-over prey stages were removed daily and the predator was provided with a fresh batch of the prey stages. In a separate experiment, the larval instar-wise prey consumption was assessed by examining the petri dishes daily for exuviae and head capsules of S. epius larvae and the amount of prey consumed during each larval instar was recorded.

Preference for prey stages The preference for the prey stages and amount of each prey stage consumed when the stages were offered together was determined by providing eggs, 2nd instar nymphs and adults of $M$. hirsutus simultaneously to the freshly hatched S. epius larvae in a petri dish. Daily and instar-wise prey consumption by S. epius larvae fed on different prey stages was recorded. For each of the above experiments 30 S. epius larvae were maintained individually on separate petri dishes.

Data analysis To test the difference in the daily and instar-wise prey consumption by the predator during its larval development, one-way ANOVA was conducted and significant differences were determined utilizing the Tukey HSD test at $P \leq 5 \%$ (SPSS Inc. 2001). For each experiment, there were six replications with five larvae per replication.

\section{Results}

Prey consumption Spalgis epius larvae completed their development in 8 days with four larval instars in the laboratory. Newly hatched 1st instar larvae of $S$. epius consumed a mean ( \pm SE) of $85.5 \pm 1.4$ eggs of $M$. hirsutus on the first day and its egg consumption increased thereafter as the development progressed. The larvae consumed the highest number of prey eggs (2416.5 \pm 24.1$)$ on the seventh day, which decreased to $1916.5 \pm 53.5$ eggs on the eighth day (Fig. 1). There was a significant difference in mean number of eggs consumed on different days $(F=1734.7$; df= 7, 40; $P<0.0001)$ except between the first and second days $(P>0.05)$.
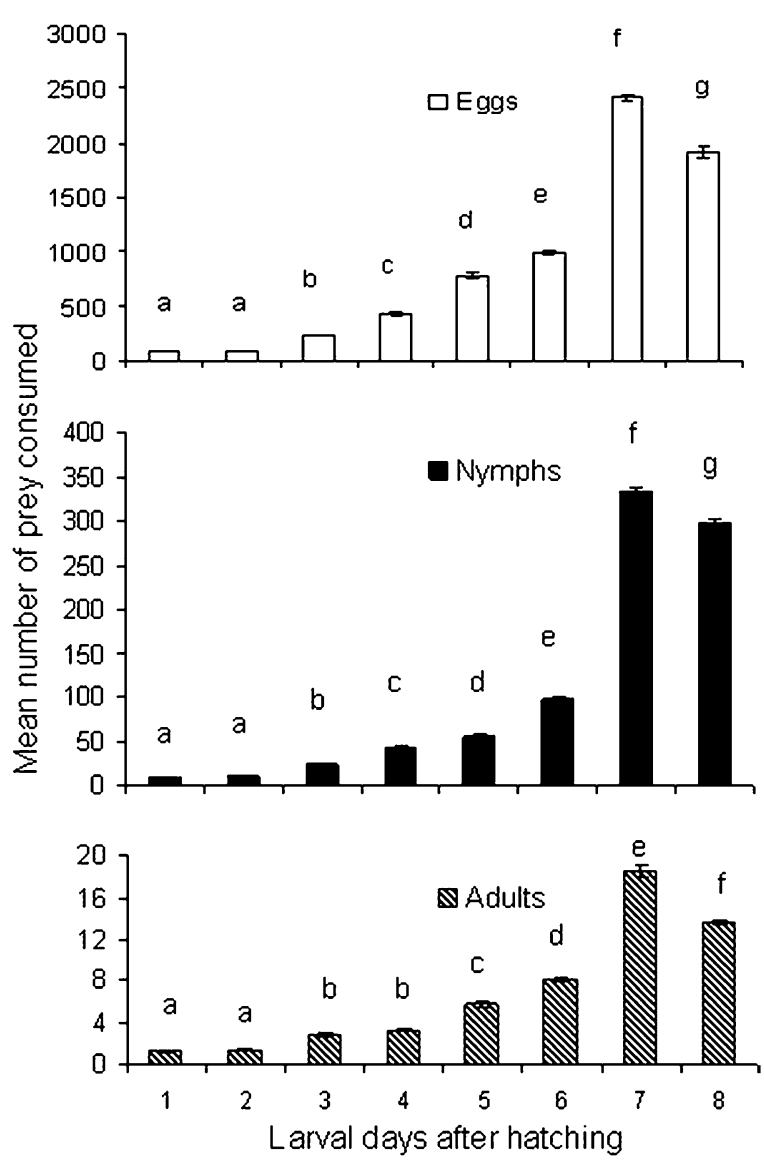

Fig. 1 Mean daily prey consumption by Spalgis epius larvae feeding on Maconellicoccus hirsutus stages offered separately. Bars with different letters indicate a significant difference at $P<$ 0.05 (one way ANOVA-Tukey HSD test) between the days within the same prey stage (vertical line indicates the SE mean prey consumption) 


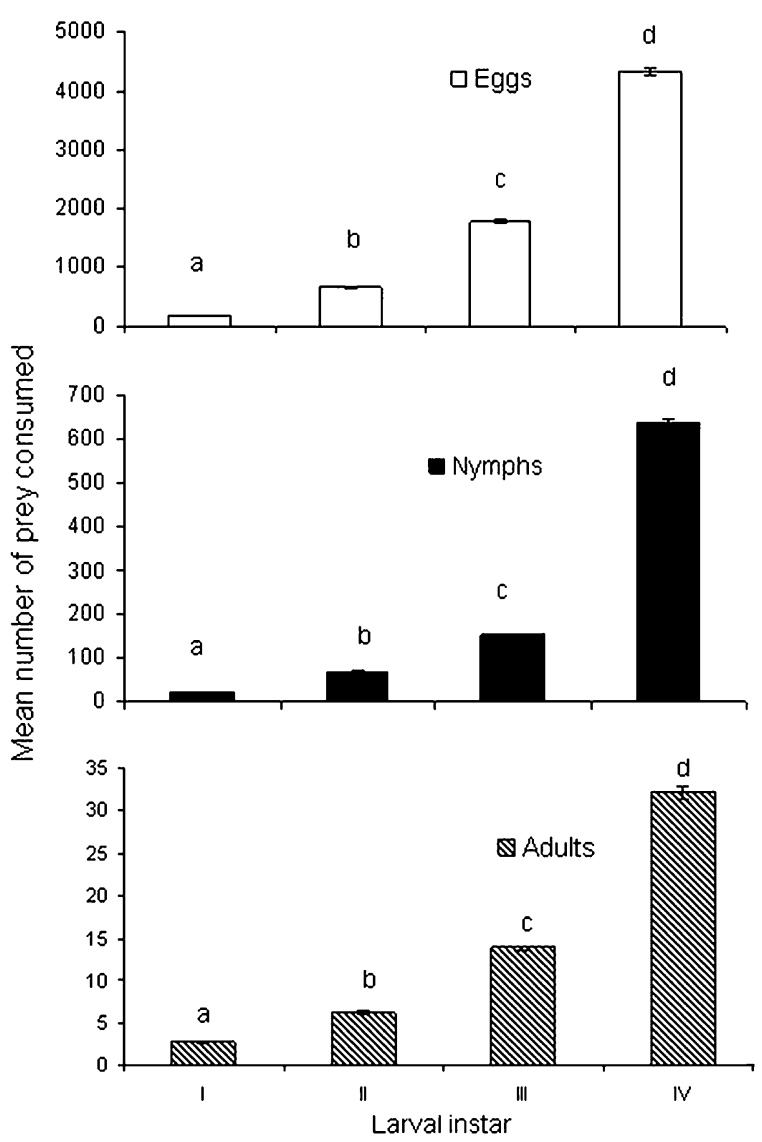

Fig. 2 Mean larval instar-wise prey consumption by Spalgis epius feeding on Maconellicoccus hirsutus stages offered separately. Bars with different letters indicate a significant difference at $P<0.05$ (one way ANOVA-Tukey HSD test) between different larval instars within the same prey stage (vertical line indicates the SE of mean prey consumption)

When the 2nd instar nymphs of $M$. hirsutus were provided as a prey, mean prey consumption by a newly hatched S. epius larva on the first day was $8.8 \pm$ 0.2 nymphs and consumption increased thereafter. The predatory larvae consumed a maximum number of nymphs $(333.0 \pm 4.4)$ on the seventh day, which decreased to $298.0 \pm 3.2$ nymphs on the eighth day. There was a significant difference in mean number of nymphs consumed on different days $(F=4518.1$; df $=$ $7,40 ; P<0.0001)$ except between the first and second days $(P>0.05)$ (Fig. 1).

When $M$. hirsutus adults were offered as a prey, freshly hatched $S$. epius larvae consumed a mean of $1.2 \pm 0.08$ adults on the first day and consumption increased thereafter to the highest mean of $18.4 \pm 0.5$ adults on the seventh day and decreased to $13.6 \pm 0.1$ adults on the eighth day. There was a significant difference in mean number of $M$. hirsutus adults consumed on different days $(F=493.0 ; \mathrm{df}=7,40 P<$ $0.0001)$ except between the first and second, and the third and fourth days $(P>0.05)$ (Fig. 1). Overall, a single $S$. epius larva consumed a mean of $6952.6 \pm$ 64.7 eggs, $878.8 \pm 6.6$ nymphs or $53.9 \pm 0.7$ adults of M. hirsutus during its entire larval development period.

With respect to larval instar-wise prey consumption, the prey consumption increased from the first to fourth larval instars of $S$. epius (Fig. 2). The mean number of prey eggs $(F=4154.9 ; \quad$ df $=3,20 ; P<0.0001)$, nymphs $(F=14259.9 ; \mathrm{df}=3,20 ; P<0.0001)$ and adults $(F=710.1 ; \mathrm{df}=3,20 ; P<0.0001)$ consumed was significantly different among the four larval instars of $S$. epius.

Preference for prey stages When the prey stages were offered together, a mean minimum of prey consumed (79.3 \pm 0.07 eggs, $0.1 \pm 0.07$ nymphs and $0.1 \pm 0.06$ adults) on the first day, with a mean maximum consumption $(514.0 \pm 32.7$ eggs, $38.9 \pm 1.3$ nymphs and $11.0 \pm 0.5$ adults) on the seventh day. Prey consumption on the eighth day decreased to $491.1 \pm$ 31.7 eggs, $36.67 \pm 1.6$ nymphs and $10.3 \pm 0.5$ adults and did not differ significantly from that on the seventh day $(F=105.6 ; \mathrm{df}=7,40 ; P=0.966)$ (Fig. 3). The first two days, $S$. epius larvae generally preferred eggs to nymphs and adults of $M$. hirsutus, whereas 3to 4-day-old larvae fed on eggs and a few nymphs as well. From the fifth day onwards, in addition to the eggs and nymphs, the larvae consumed adults of the prey. Mean prey consumption during the entire larval

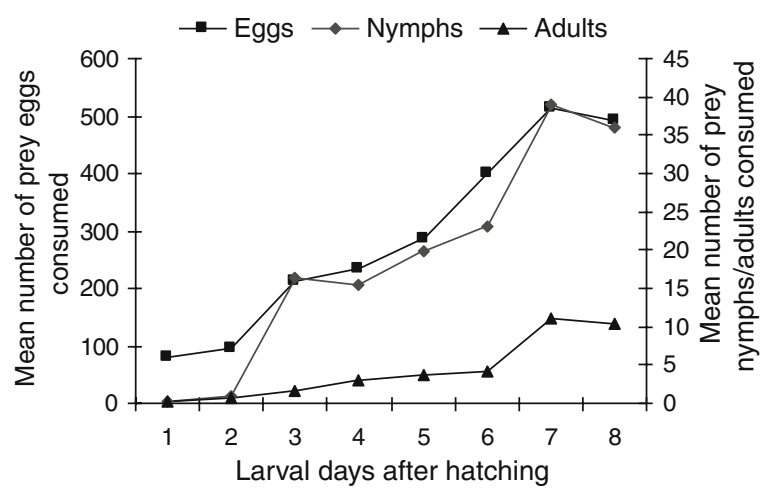

Fig. 3 Mean daily prey consumption by Spalgis epius larvae feeding on Maconellicoccus hirsutus stages offered together 


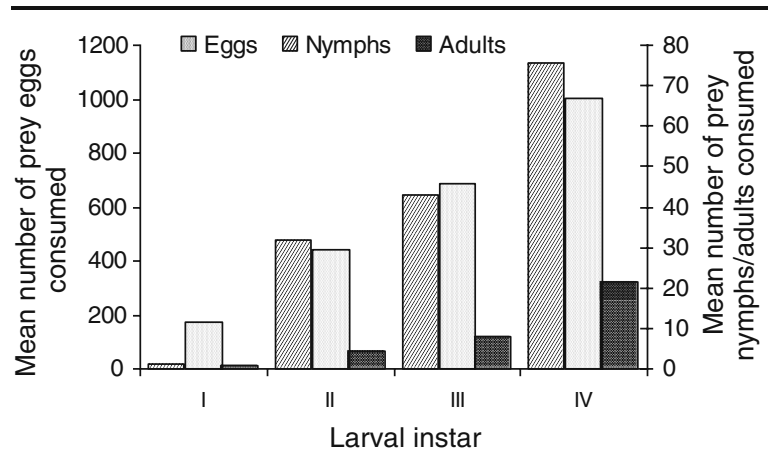

Fig. 4 Mean larval instar-wise prey consumption by Spalgis epius feeding on Maconellicoccus hirsutus stages offered together

development period of $S$. epius was $2358.3 \pm 36.7$ eggs, $151.2 \pm 6.8$ nymphs and $34.3 \pm 1.7$ adults when the prey stages were offered all together.

The prey consumption increased significantly from the 1st to 4th instar larvae of S. epius $(F=293.2$; df= 7, 40; $P<0.0001$ ) (Fig. 4). The 1st and 2nd instar larvae usually preferred eggs to nymphs and adults of $M$. hirsutus, whereas 3rd and 4th larval instars fed on all stages of the prey. The 1st and 2nd instar larvae of S. epius were almost sedentary, whereas the $3 \mathrm{rd}$ and 4th instar larvae crawl while feeding.

\section{Discussion}

Spalgis epius larvae were able to prey successfully on the large number of M. hirsutus eggs, nymphs and adults. A mean daily consumption of prey stages by the developing larvae of $S$. epius increased significantly on the seventh day but decreased significantly on the eighth day as the larva slows down its feeding and prepares for the prepupal stage. In general, there was a significant difference in prey consumption by $S$. epius larvae on different days. Preliminary observations made in the field on $S$. epius revealed that a fully grown larva consumes 300 nymphs of $M$. hirsutus per day (Pushpaveni et al. 1973); a mean of 132 eggs, 260 nymphs and 75 adults of $M$. hirsutus during the final stage of development (Gowda et al. 1996); and 22.3 ovisacs and 121.6 nymphs and adults of P. marginatus (Thangamalar et al. 2010). In the present study, when the different prey stages were offered either separately or together, the 4th instar larvae of S. epius consumed more eggs than nymphs and adults of $M$. hirsutus. This could be due to the size of the eggs, which are very small compared with that of the nymphs and adults, as observed in the case of predation by $C$. montrouzieri on M. hirsutus (Mani and Thontadarya 1987). The daily and larval instarwise prey consumption of $S$. epius increased with their progressing development, as reported with $C$. montrouzieri preying on M. hirsutus (Mani and Thontadarya 1987).

Vinod Kumar et al. (2008b) and Thangamalar et al. (2010) reported that a single $S$. epius larva consumed 416.4 eggs, 449.2 nymphs and 158.3 adults of $P$. citri; and 48.1 ovisacs and 210.9 nymphs and adults of $P$. marginatus when all the prey stages were offered together. S. epius larva consumed more eggs and fewer nymphs and adults of $M$. hirsutus when compared with that of $P$. citri and P. marginatus. On the whole, an $S$. epius larva consumed about $2543 \mathrm{M}$. hirsutus stages, which is more than that of $P$. citri and $P$. marginatus. Hence, it could be used as a major predator of $M$. hirsutus. In the case of C. montrouzieri, a single grub during its entire development consumes 881.3 eggs or 295 nymphs or 27.5 adults of M. hirsutus (Mani and Thontadarya 1987) or preys exclusively on 1325 or 3330 P. citri eggs in the laboratory (Oncuer and Bayhan 1982; Whitecomb 1940). Again, the overall consumption of prey stages by $S$. epius is more than that of $C$. montrouzieri. Furthermore, S. epius larvae fed only on eggs, and nymphs or adults of $M$. hirsutus were able to complete their normal development successfully, whereas $C$. montrouzieri fed only on the 1st instar nymphs of $P$. citri, which was unable to complete its normal development (Oncuer and Bayhan 1982). The normal development of $S$. epius on any stages of $M$. hirsutus indicated that it is able to survive successfully and bring down the prey population effectively.

The completely sedentary early stage larvae of $S$. epius (i.e., the 1 st and 2 nd instar larvae) in the feeding chamber constructed within the ovisac of the prey, preferred eggs to nymphs and adults of $M$. hirsutus as reported by Dinesh et al. (2010). This could be due to the constant movement of young $M$. hirsutus nymphs, which normally escape from predation; and the almost sedentary older nymphs and adults of $M$. hirsutus are usually not available around the feeding chamber. While feeding on the eggs, the young larvae sometimes nibbled the nymphs and adults of $M$. hirsutus and such injured prey were killed. However, if the prey eggs were not available for feeding, the 
young larvae preyed on the nymphs and adults of the prey and could complete their development. From the fifth day onwards (i.e., the 3rd and 4th instar larvae), the well developed and large sized predatory larva (6.6-11.4 mm) consumed all stages of M. hirsutus.

Our observations on the feeding potential of $S$. epius indicated that the predator fed voraciously on all stages of the prey. It was reported that at the rate of $3.7 \mathrm{~S}$. epius larvae per shoot, $S$. epius was able to bring down a $P$. lilacinus population from 45.50 to 0.4 bugs per shoot in the ber crop within a month (Mani and Krishnamoorthy 1996). It was also reported that 13-20 S. epius larvae reduced $54.78-68.38 \%$ of different species of mealybug ( $P$. citri, P. lilacinus and $F$. virgata) populations in coffee in 10 days (Rahiman and Vijayalakshmi 1998).

Successful biological control of any pest species depends on at what rate and extent a natural enemy is able to suppress the pest population. Our study showed that a single $S$. epius larva during its 8-day development preyed successfully upon a large number of M. hirsutus stages. In addition, S. epius larva feeding on a large number of eggs of $M$. hirsutus not only bring down the pest population but also reduce drastically the subsequent damage caused by developing nymphs and adults of the pest. Furthermore, lycaenids feeding on Hemiptera live among their prey without provoking an escape response or an attack response from the ant mutualists of Hemiptera (Pierce et al. 2002). Similarly, S. epius larvae successfully feed on mealybugs although some species of mealybug-tending ants are hostile to the predatory larvae (Venkatesha 2005; Vinod Kumar et al. 2008a). Mealybug-mutualist ants hinder the activities of $C$. montrouzieri in the field (Le Pelley 1968). In this study it was determined that $S$. epius can consume a large number of $M$. hirsutus and thus could be utilized as a major biological control agent of $M$. hirsutus in India and worldwide.

Acknowledgements The second author is grateful to the University Grants Commission (UGC), New Delhi, India for providing financial assistance (No. F. No. 33-344/2007) to carry out the above work.

\section{References}

Ali, M. (1978). A report on the wax scales, on Ceroplastes pseudoceriferus Green, and Chloropulvinaria polygonata
(Ckll.) (Homoptera: Coccidae) on mango and their natural enemies. Bangladesh Journal of Zoology, 6, 69-70.

Anon. (1995). Technology for production of natural enemies. Bangalore, India: Project Directorate of Biological Control, Indian Council of Agricultural Research.

Bingham, C. T. (1907). The fauna of British India including Ceylon and Burma. Butterflies. London, UK: Taylor and Francis.

Browning, H. W. (1992). Overview of biological control of homopterous pests in the Caribbean. The Florida Entomologist, 75, 440-446.

Chacko, M. J., Bhat, P. K., \& Ramanarayan, E. P. (1977). New records of coccoidea with notes on natural enemies of Planococcus spp. on coffee in India. Journal of Coffee Research, 7, 69-71.

De Niceville, L. (1890). The butterflies of India, Burma and Ceylon. Calcutta, India: Calcutta Central Press Co. Ltd.

Dinesh, A. S., Venkatesha, M. G., \& Ramakrishna, S. (2010). Development, life history characteristics and behaviour of mealybug predator, Spalgis epius (Westwood) (Lepidoptera: Lycaenidae) on Planococcus citri (Risso) (Homoptera: Pseudococcidae). Journal of Pest Science, 83, 339-345.

Franco, J. C., Gross, S., Carvalho, C. J., Blumberg, D., \& Mendel, Z. (2001). The citrus mealybug in citrus groves in Israel, Portugal and California: fruit injury and biological control as related to seasonal activity. Phytoparasitica, 29, 86.

Gowda, D. K. S., Manjunath, D., Datta, R. K., \& Kumar, P. (1996). Spalgis epius Westwood (Lepidoptera: Lycaenidae) a potential predator of mulberry mealybug, Maconellicoccus hirsutus. Insect Environment, 2, 87-88.

Hoy, M. A., Hamon, A., \& Nguyen, R. (2002). Pink hibiscus mealybug, Maconellicoccus hirsutus (Green). Resource document. Florida Cooperative Extension Service, Institute of Food and Agricultural Sciences, University of Florida. http://creatures.ifas.ufl.edu. Accessed 17 November 2009.

Kairo, M. T. K., Poolard, G. V., Pterkin, D. D., \& Lopez, V. F. (2000). Biological control of the hibiscus mealybug, Maconellicoccus hirsutus Green (Hemiptera: Psedococcidae) in the Caribbean. Integrated Pest Management Reviews, 5, 241-254.

Le Pelley, R. H. (1943). An oriental mealybug (Pseudococcus lilacinus) and its natural enemies. Transactions of Royal Entomological Society London, 93, 73-93.

Le Pelley, R. H. (1968). Pests of coffee. London, UK: Longmans Green and Co. Ltd.

Lohman, D. J., \& Samarita, V. U. (2009). The biology of carnivorous butterfly larvae (Lepidoptera: Miletinae: Miletini) and their ant-tended hemipteran prey in Thailand and the Philippines. Journal of Natural History, 43, 569-581.

Mani, M., \& Thontadarya, T. S. (1987). Development and feeding potential of coccinellid predator Cryptolaemus montrouzieri Mul. on the grape mealybug, Maconellicoccus hirsutus (Green). Journal of Biological Control, 1, 19-22.

Mani, M., \& Krishnamoorthy, A. (1996). Biological suppression of oriental mealybug, Planococcus lilacinus (Ck1l.) on ber. Pest Management and Horticulture Ecosystem, 2, 49-50.

Meyerdirk, D. E., Warkentin, R., Attavian, B., Gersabeck, E., Francis, A., Adams, J., et al. (2002). Biological control of pink hibiscus mealybug project manual. Washington, DC: United States Department of Agriculture. 
Oncuer, C., \& Bayhan, N. (1982). An investigation into the feeding capacity of Cryptolaemus montrouzieri. Turkiye Bitki Koruma Dergesi, 6, 85-90.

Pierce, N. E., Braby, M. F., Heath, A., Lohman, D. J., Mathew, J., Rand, D. B., et al. (2002). The ecology and evolution of ant association in the Lycaenidae (Lepidoptera). Annual Review of Entomology, 47, 733-771.

Pushpaveni, G., Rao, P. R. M., \& Rao, P. A. (1973). A new record of Spalgis epius Westwood as a predator of Maconellicoccus hirsutus Gr. on mesta (Hibiscus sabdariffa L.). Indian Journal of Entomology, 32, 71.

Rahiman, A. P., \& Vijayalakshmi, C. K. (1998). Spalgius epius Westwood (Lepidoptera: Lycaenidae) - a potential predator of coffee mealy bugs. Journal of Entomological Research, 22, 191-192.

Rao, V. P., Ghani, M. A., Sankaran, T., \& Mature, K. C. (1971). $A$ review of the biological control of insects and other pests in South-East Asia and the Pacific region. Farnham Royal, UK: Commonwealth Agricultural Bureaux.

Reddy, G. V. P., Muniappan, R., Cruz, Z. T., Naz, F., Bamba, J. P., \& Tenorio, J. (2009). Present status of Maconellicoccus hirsutus (Hemiptera: Pseudococcidae) in the Mariana Islands and its control by two fortuitously introduced natural enemies. Journal of Economic Entomology, 102, 1431-1439.

Roltsch, W. J., Meyerdirk, D. E., Warkentin, R., Andress, E. R., \& Carrera, K. (2006). Classical biological control of pink hibiscus mealybug, Maconellicoccus hirsutus (Green), in southern California. Biological Control, 37, 155-166.
SPSS Inc. (2001). SPSS for windows, Rel. 11.0.0. Chicago, IL, USA: SPSS Inc.

Thangamalar, A., Subramaian, S., \& Mahalingam, C. A. (2010). Bionomics of papaya mealybug, Paracoccus marginatus and its predator Spalgius epius in mulberry ecosystem. Karnataka Journal of Agricultural Sciences, 23, 39-41.

Venkatesha, M. G. (2005). Why is homopterophagous butterfly, Spalgis epius (Westwood) (Lepidoptera: Lycaenidae) amyrmecophilous? Current Science, 89, 245-246.

Venkatesha, M. G., Shashikumar, L., \& Gayathri Devi, S. S. (2004). Protective devices of the carnivorous butterfly, Spalgis epius (Westwood) (Lepidoptera: Lycaenidae). Current Science, 87, 571-572.

Vinod Kumar, P. K., Vasudev, V., Seetharama, H. G., Irulandi, S., \& Sreedharan, K. (2006). Biology and biometry of the lycaenid predator Spalgis epius. Journal of Coffee Research, 34, 72-104.

Vinod Kumar, P. K., Vasudev, V., Seetharama, H. G., Irulandi, S., \& Sreedharan, K. (2008a). Attendant ants and activity of Spalgis epius. Journal of Coffee Research, 36, 3845.

Vinod Kumar, P. K., Vasudev, V., Seetharama, H. G., Irulandi, S., \& Sreedharan, K. (2008b). Predatory potential of the lycaenid Spalgis epius. Journal of Coffee Research, 36, 25-29.

Whitecomb, W. D. (1940). Biological control of mealybugs in green houses. Bulletin of Massachusetts Agriculture Experiment Station, 375, 22. 